
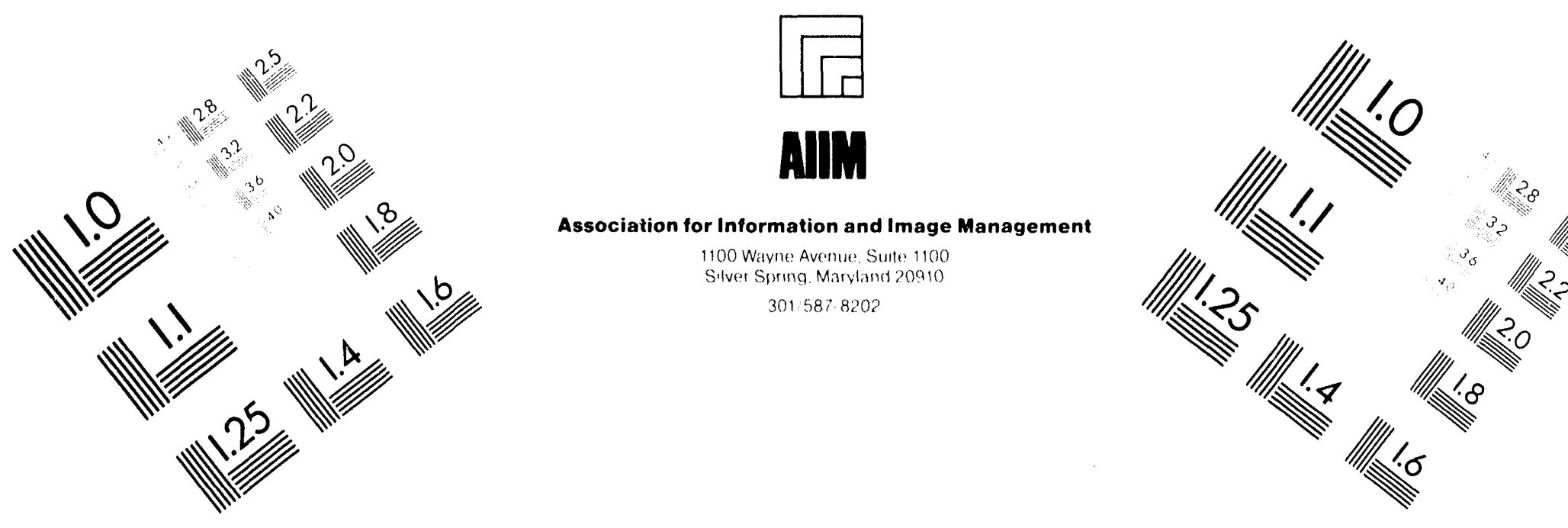

Centimeter

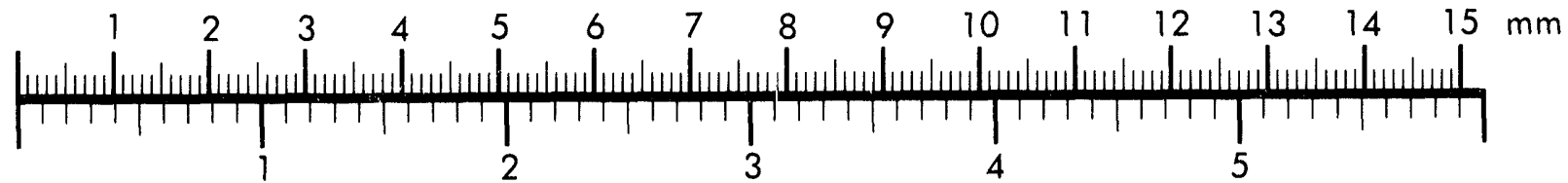

Inches
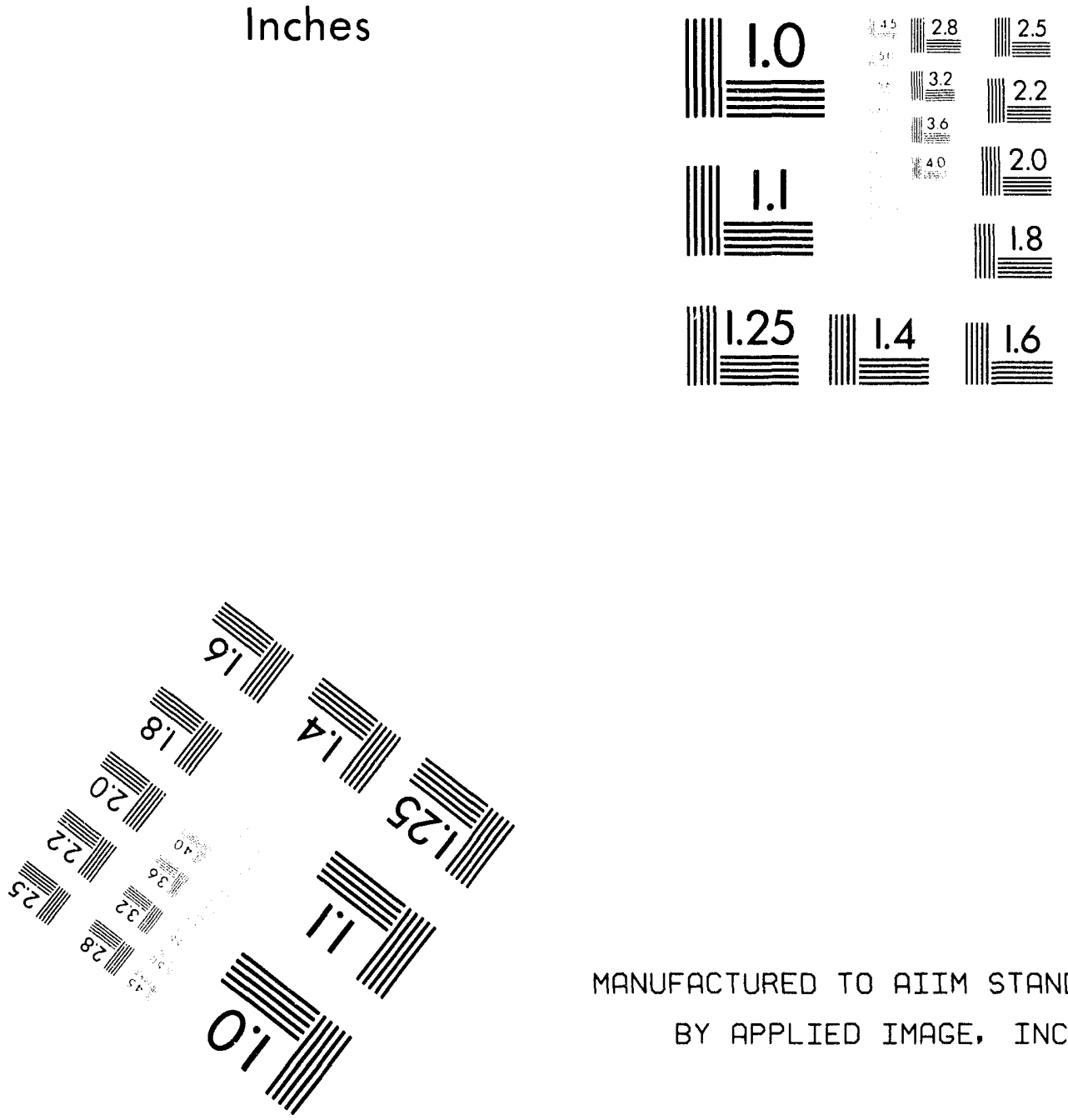

MANUFACTURED TO AIIM STANDARDS

BY APPLIED IMAGE, INC.

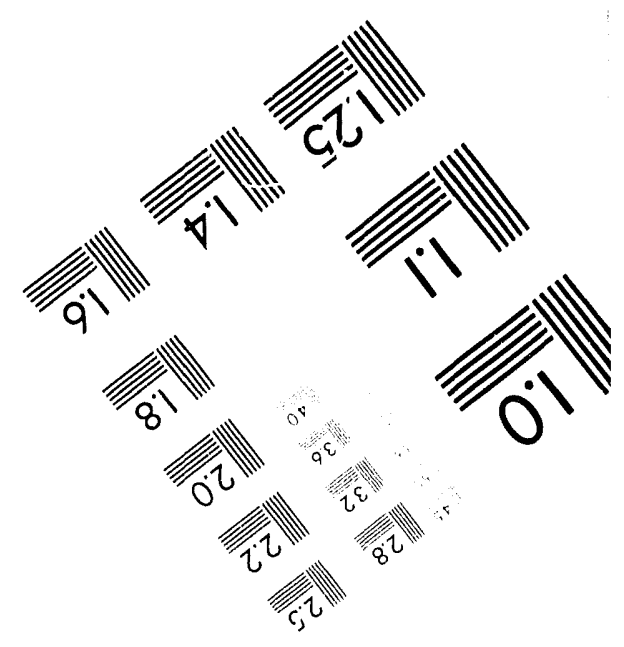



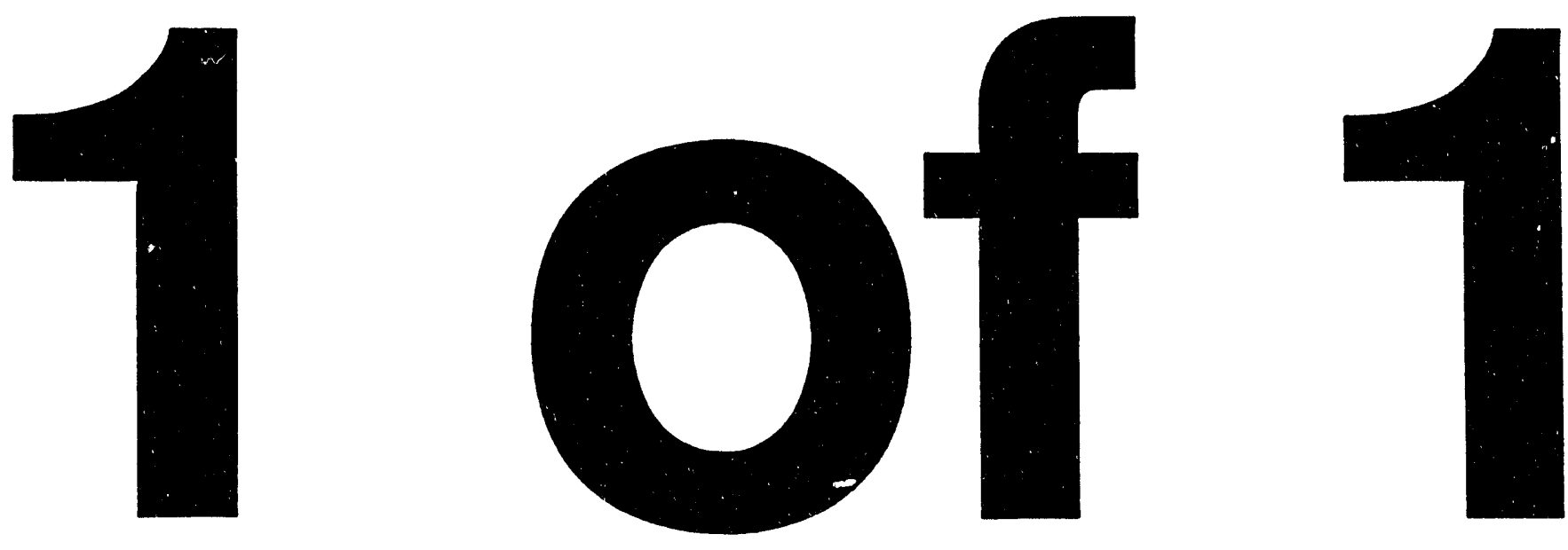
WSRC-TR-93-475

\section{EFFECTS OF INTERFERING CONSTITUENTS ON TRITIUM SMEARS (U)}

G. D. Levi, Jr. and K. E. Cheeks

Westinghouse Savannah River Company

Savannah River Site

Aiken, SC 29808

The information contained in this article was developed during the course of work under Contract No. DE-AC09-89SR18035 with the U. S. Department of Energy. By acceptance of this paper, the publisher and/or recipient acknowledges the U. S. Government's right to retain a nonexclusive, royalty-free license in and to any copyright covering this paper along with the right to reproduce, and to authorize others to reproduce all or part of the copyrighted paper. 


\section{DISCLAIMER}

This repor was prepared as an account of work sponsored by an ageacy of the United States Governmeat. Neither the United States Governmeat nor any agency thereof, nor any of their employees, makes any warranty, express or implied, or assumes any legal liability or responsibility for the accuracy. completeness, or usefulaess of any information. apparatus, product. or process disclosed, or represents that its use would not infringe privately owned rights. Reference herein to any specific commercial product, process, or service by trade name, trademark, manufacturer, or otherwise does not necessarily constitute or imply its endorsemeat, recommendation, or favoring by the United States Government or any ageacy thereof. The views and opinions of authors expressed berein do not necersarily state or reflect those of the United States Governmeat or any ageacy ihereof.

This report has beea reproduced directly from the best available copy.

Available to DOE and DOE contractors from the Office of Scieatific and Technical Informatioa. P. O. Box 62. Oak Ridge. TN 37831: prices available from (615) $576-8401$.

Available to the public from the National Techaical Informacioa Service, U. S. Deparmeat of Commerce. 5285 Port Royal Rd.. Springfield. VA 22161 
WSRC-TR-93-475

\title{
EFFECTS OF INTERFERING CONSTITUENTS ON TRITIUM SMEARS (U)
}

By G. D. Levi, Jr. and K. E. Cheeks

\author{
Westinghouse Savannah River Company \\ Savannah River Slte \\ Alken, SC 29808
}

\section{INTRODUCTION}

Tritium smears are performed by Health Protection Operations (HPO) to assess transferable contamination on work place surfaces, materials for movement outside Radiologically Controlled Areas (RCA), and product containers being shipped between facilities. Historically, gas proportional counters were used to detect transferable tritium contamination collected by smearing. Because tritium is a low-energy beta emitter, gas proportional counters do not provide the sensitivity or the counting efficiency to accurately measure the tritium activity on the smear. Liquid Scintillation Counters (LSC) provide greater counting efficiency for the low-energy beta particles along with greater reliability and reproducibility compared to gas flow proportional counters. The purpose of this technical evaluation was to determine the effects of interfering constituents such as filters, dirt and oil on the counting efficiency and tritium recoveries of tritium smears by LSC.

\section{DISCUSSION}

To validate the analytical procedure for the tritium smear method currently used i. the Water Quality Laboratory (WQL), a technical evaluation was performed to determine the effects of interfering constituents on counting efficiency and tritium recoveries. To accomplish this, scintillation vials containing tritium and interfering constituents were analyzed and compared to scintillation vials containing only tritium.

HPO obtains the vials from the WQL before performing smears. The WQL currently performs tritium smear analyses by first pipetting 3 milliliters $(\mathrm{mL})$ of distilled water into $25 \mathrm{~mL}$ plastic scintillation vials. An additional vial containing $3 \mathrm{~mL}$ of distilled water is prepared for background determinations and two empty vials are supplied for quality control standards. Using a dry Whatman 50 
filter paper, HPO personnel smear the surface of the survey material. The smears are placed in vials containing distilled water. Filter papers from the packaged lot used to perform the tritium smears are placed in the background vial and the quality control standard vials. After capping the vials that contain the smear and distilled water, the contents are swirled to elute tritium from the smear into solution. HPO submits sample vials, background vials, and quality control standard vials to the WQL for tritium smear analyses.

To the quality control standard vials, the WQL pipets $1 \mathrm{~mL}$ of a $1000 \mathrm{dpm} / \mathrm{mL}$ tritiated water standard onto the smear. An additional $2 \mathrm{~mL}$ of distilled water is pipetted into the quality control standard vials to elute tritium from the smear into solution. Then $20 \mathrm{~mL}$ of Optifluor ${ }^{\circledR}$ scintillation cocktail is dispensed into each vial. After capping, the contents in the vials are mixed until the smear's white coating is dissolved. After all vials are held under dark conditions for 20 minutes, background vials are counted for 5 minutes using a Beckman LS6000LL liquid scintillation counter. The sample vials and quality control standard vials are counted for 2 minutes. The sample and QC counts are automatically corrected for background by the LSC software. The sample result for each smear is reported to HPO in disintegrations per minute (dpm).

The effects on counting efficiency and tritium recoveries were evaluated by comparing the vials that contained no smears to the viais that contained clean smears, smears with increasing quantities of dirt, smears with increasing quantities of unused oil, and smears with increasing quantities of waste oil. The test samples were placed into scintillation vials and $1 \mathrm{~mL}$ of tritiated water standard (1300 dpm) was pipetted onto the surface of each smear. After $2 \mathrm{~mL}$ of distilled water was pipetted onto the surface of each smear, the vials were capped and mixed to ensure that tritium had been eluted from the smears. 20 $\mathrm{mL}$ of Optifluor ${ }^{\circledR}$ scintillation cocktail was dispensed into each vial, and the vials were capped and mixed until the smear's coating had dissolved. The vials were dark adapted for 20 minutes and then counted for 2 minutes using an LSC. 


\section{RESULTS}

\section{Clean Smears}

Table 1 shows a reduction of approximately $2 \%$ in the counting efficiency between the scintillation vial that contains a clean smear and a scintillation vial that contains no smears. The $2 \%$ reduction in the counting efficiency was due to the quench caused by the filters in the scintillation vials. By comparing the known tritium value to the measured tritium values, table 2 shows that the clean smears do not interfere with the tritium analyses because the tritium recoveries were approximately $100 \%$.

Table 1. Effects of Clean Smears on Counting Efficiency

\begin{tabular}{ccc}
$\begin{array}{c}\text { Sample } \\
\text { Number }\end{array}$ & $\begin{array}{c}\text { No Smears } \\
\text { (Efficiency) }\end{array}$ & $\begin{array}{c}\text { Clean Smears } \\
\text { (Efficiency) }\end{array}$ \\
\hline 1 & 41.18 & 40.22 \\
2 & 41.22 & 40.50 \\
3 & 41.24 & 40.28 \\
4 & 41.22 & 40.36 \\
5 & 41.17 & 39.36 \\
6 & 41.01 & 39.99 \\
7 & 41.11 & 40.43 \\
8 & 41.04 & 39.76 \\
9 & 41.24 & 40.67 \\
10 & $\frac{41.17}{41.16}$ & $\frac{40.33}{40.20}$
\end{tabular}

Table 2. Effects of Clean Smears on Tritium Recovery

\begin{tabular}{cc}
$\begin{array}{c}\text { Sample } \\
\text { Number }\end{array}$ & $\begin{array}{c}\text { Known Value } \\
\text { (dpm) }\end{array}$ \\
\hline 1 & 1314.44 \\
2 & 1314.44 \\
3 & 1314.44 \\
4 & 1314.44 \\
5 & 1314.44 \\
6 & 1314.44 \\
7 & 1314.44 \\
8 & 1314.44 \\
9 & 1314.44 \\
10 & 1314.44
\end{tabular}

$\begin{array}{cc}\begin{array}{c}\text { Measured Value } \\ \text { (dpm) }\end{array} & \begin{array}{c}\text { Recovery } \\ 1320.98\end{array} \\ \frac{(\%)}{101} \\ 1327.92 & 101 \\ 1355.17 & 103 \\ 1349.87 & 103 \\ 1258.14 & 96 \\ 1324.89 & 101 \\ 1399.41 & 106 \\ 1333.82 & 101 \\ 1347.98 & 103 \\ 1249.12 & 95\end{array}$

Average Recovery $=101 \%$ Standard Deviation $=3 \%$ 


\section{Dirty Smears}

Table 3 shows a reduction of the counting efficiency as the quantity of dirt on the smears increased. The reduction of the counting efficiency was due to selfabsorption that was caused by increasing quantities of impurities on the smears. By comparing the known tritium values to the measured tritium values, tables $3 \& 4$ show that the tritium recoveries were approximately $100 \%$ except when the counting efficiency decreased below $30 \%$. The decrease in counting efficiency caused tritium recoveries to fluctuate from approximately $85 \%$ to $100 \%$.

Table 3. Effects of Dirty Smears on Counting Efficiency

$\begin{array}{ccc}\begin{array}{c}\text { Sample } \\ \text { Number }\end{array} & \begin{array}{c}\text { No Smears } \\ \text { (Etficiency) }\end{array} & \begin{array}{c}\text { Dirt Smears } \\ \text { (Etficiency) }\end{array} \\ 2 & 41.18 & 39.23 \\ 2 & 41.22 & 38.99 \\ 3 & 41.24 & 36.83 \\ 4 & 41.22 & 37.28 \\ 5 & 41.17 & 36.42 \\ 6 & 41.01 & 27.86 \\ 7 & 41.11 & 26.09 \\ 8 & 41.04 & 26.69 \\ 9 & 41.24 & 31.81 \\ 10 & 41.17 & 25.31\end{array}$

* As the sample numbers increase the quantity of dirt on the smear increases. (Clean Smear to Saturated Smear)

Table 4. Effects of Dirty Smears on Tritium Recovery

$\begin{array}{cccc}\begin{array}{c}\text { Sample } \\ \text { Number }\end{array} & \begin{array}{c}\text { Known Value } \\ (\mathrm{dpm})\end{array} & \begin{array}{c}\text { Measured Value } \\ \frac{(\mathrm{dpm})}{1314.44}\end{array} & \begin{array}{c}\text { Recovery } \\ \left(\frac{\%}{1292.56}\right)\end{array} \\ 2 & 1314.44 & 1275.02 & 98 \\ 3 & 1314.44 & 1319.95 & 97 \\ 4 & 1314.44 & 1278.34 & 100 \\ 5 & 1314.44 & 1330.58 & 97 \\ 6 & 1314.44 & 1233.28 & 94 \\ 7 & 1314.44 & 1125.43 & 86 \\ 8 & 1314.44 & 1145.04 & 87 \\ 9 & 1314.44 & 1231.07 & 94 \\ 10 & 1314.44 & 1264.67 & 96 \\ & & \begin{array}{c}\text { Average Recovery }= \\ \text { Standard Deviation }=\end{array} & 95 \% \\ & & 5 \%\end{array}$

" As the sample numbers increase the quantity of dirt on the smear increases. (Clean Smear to Saturated Smear) 


\section{Clean Oil Smears}

Table 5 shows a reduction of approximately $5 \%$ in the counting efficiency between the scintillation vial that contains clean oil smears and scintillation vials that contain no smears. The reduction of the counting efficiency was due to color quench caused by the oil on the smears. By comparing the known tritium value to the measured tritium values, table 6 shows that the quench calibration corrected for the decrease in counting efficiency so tritium recoveries were approximately $100 \%$.

Table 5. Effects of Clean Oil Smears on Counting Efficiency

\begin{tabular}{ccc}
$\begin{array}{c}\text { Sample } \\
\text { Number }\end{array}$ & $\begin{array}{c}\text { No Smears } \\
\text { (Efficiency) }\end{array}$ & $\begin{array}{c}\text { Clean Oil Smears } \\
\text { (Efficiency) }\end{array}$ \\
\hline 1 & 41.18 & 39.73 \\
2 & 41.22 & 39.65 \\
3 & 41.24 & 39.48 \\
4 & 41.22 & 39.20 \\
5 & 41.17 & 39.09 \\
6 & 41.01 & 39.18 \\
7 & 41.11 & 38.86 \\
8 & 41.04 & 38.91 \\
9 & 41.24 & 38.41 \\
10 & 41.17 & 38.35
\end{tabular}

* As the sample numbers increase the quantity of clean oil on the smear increases. (20 to 200 microliters)

Table 6. Effects of Clean Oil Smears on Tritium Recovery

\begin{tabular}{cccc}
$\begin{array}{c}\text { Sample } \\
\text { Number }\end{array}$ & $\begin{array}{c}\text { Known Value } \\
\text { (dpm) }\end{array}$ & $\begin{array}{c}\text { Measured Value } \\
(\text { dpm) }\end{array}$ & $\begin{array}{c}\text { Recovery } \\
(\%)\end{array}$ \\
\hline 1 & 1314.44 & 1321.03 & 100 \\
2 & 1314.44 & 1260.63 & 96 \\
3 & 1314.44 & 1417.89 & 108 \\
4 & 1314.44 & 1236.66 & 94 \\
5 & 1314.44 & 1339.87 & 102 \\
6 & 1314.44 & 1302.52 & 99 \\
7 & 1314.44 & 1287.37 & 98 \\
8 & 1314.44 & 1271.80 & 97 \\
9 & 1314.44 & 1309.08 & 100 \\
10 & 1314.44 & 1327.97 & 101 \\
& & Average Recovery $=$ & $100 \%$ \\
& & Standard Deviation $=$ & $4 \%$
\end{tabular}

* As the sample numbers increase the quantity of clean oil on the smear increases. (20 to 200 microliters) 


\section{Waste Oil Smears}

Table 7 shows a reduction of counting efficiency as the quantity of waste oil on the smears increased. The reduction of the counting efficiency was due to color quench caused by the waste oil on the smears. The color quench caused by the waste oil smear was more severe than clean oil smear's color quench. By comparing the known tritium values to the measured tritium values, tables 7 \& 8 show that the tritium recoveries started at $100 \%$ with a counting efficiency of $23 \%$ but as the quantities of impurities were increased the tritium recoveries were reduced to $42 \%$ and counting efficiency to below $10 \%$.

Table 7. Effects of Waste Oil Smears on Counting Efficiency

\begin{tabular}{ccc}
$\begin{array}{c}\text { Sample } \\
\text { Number }\end{array}$ & $\begin{array}{c}\text { No Smears } \\
\text { (Efficiency) }\end{array}$ & $\begin{array}{c}\text { Waste Oil Smears } \\
\text { (Efficiency) }\end{array}$ \\
\hline 1 & 41.18 & 23.02 \\
2 & 41.22 & 14.69 \\
3 & 41.24 & 11.98 \\
4 & 41.22 & 9.29 \\
5 & 41.17 & 7.39 \\
6 & 41.01 & 4.97 \\
7 & 41.11 & 4.27 \\
8 & 41.04 & 4.05 \\
9 & 41.24 & 2.65 \\
10 & 41.17 & 2.81
\end{tabular}

"As the sample numbers increase the quantity of waste oil on the smear increases. (20 to 200 microliters)

Table 8. Effects of Waste Oil Smears on Tritium Recovery

\begin{tabular}{|c|c|c|c|}
\hline \multirow[t]{2}{*}{$\begin{array}{c}\text { Sample } \\
\text { Number } \\
1 \\
2 \\
3 \\
4 \\
5 \\
6 \\
7 \\
8 \\
9 \\
10\end{array}$} & $\begin{array}{c}\begin{array}{c}\text { Known Value } \\
\text { (dpm) }\end{array} \\
1314.44 \\
1314.44 \\
1314.44 \\
1314.44 \\
1314.44 \\
1314.44 \\
1314.44 \\
1314.44 \\
1314.44 \\
1314.44\end{array}$ & $\begin{array}{c}\begin{array}{c}\text { Measured Value } \\
\text { (dpm) }\end{array} \\
\frac{1340.93}{1112.50} \\
959.27 \\
882.19 \\
898.93 \\
773.44 \\
760.19 \\
667.03 \\
564.33 \\
548.95\end{array}$ & $\begin{array}{c}\text { Recovery } \\
(\%) \\
102 \\
85 \\
73 \\
67 \\
68 \\
59 \\
58 \\
51 \\
43 \\
42\end{array}$ \\
\hline & & $\begin{array}{l}\text { Average Recovery }= \\
\text { Standard Deviation }=\end{array}$ & $\begin{array}{l}65 \% \\
19 \%\end{array}$ \\
\hline
\end{tabular}

"As the sample numbers increase the quantity of waste oil on the smear increases. (20 to 200 microliters) 


\section{SUMMARY}

This report concludes that smears in the scintillation cocktail do not adversely effect the counting efficiency or the tritium recoveries. The effects of dirt on the smears can cause self-absorption of the tritium beta particles resulting in reduction of counting efficiency. If the counting efficiency for the smears that contain dirt is reduced below $30 \%$, the tritium recoveries will be adversely effected with a lower tritium activity determination. The effects of oil on the smears can cause color quench of the photons emitted by the scintillators. The effects of color quench due to oil is much greater for waste oil than clean oil. The color quench caused by the oil on the smears can be corrected by two methods. The first method is to enable the color quench option on the LSC. The second method is to establish a quench curve with oil as the quenching agent. If these two methods are not available, data has shown that color quench will cause reduction in the counting efficiency. If the counting efficiency for the smears that contain oil is reduced below $20 \%$, the tritium recoveries will be adversely effected with a loss of tritium activity.

\section{REFERENCES}

1. Klein, R. C., Linins, I., and Gershey, E. L. 1992. Detecting Removable Surface Contamination. Health Physics. 62: 186-189.

2. Takiue, M., Fujii, H., Aburai, T., and Ishikawa, H. 1989. Usefulness of Water-Soluble Paper for Smear Test of Low-Energy Beta and Alpha Emitters Using a Liquid Scintillation Technique. Health Physics. 56(3): 367-371.

3. Packard Instrument Company, 1993. Application Note; ABA-006, Meriden, Connecticut 06450. 

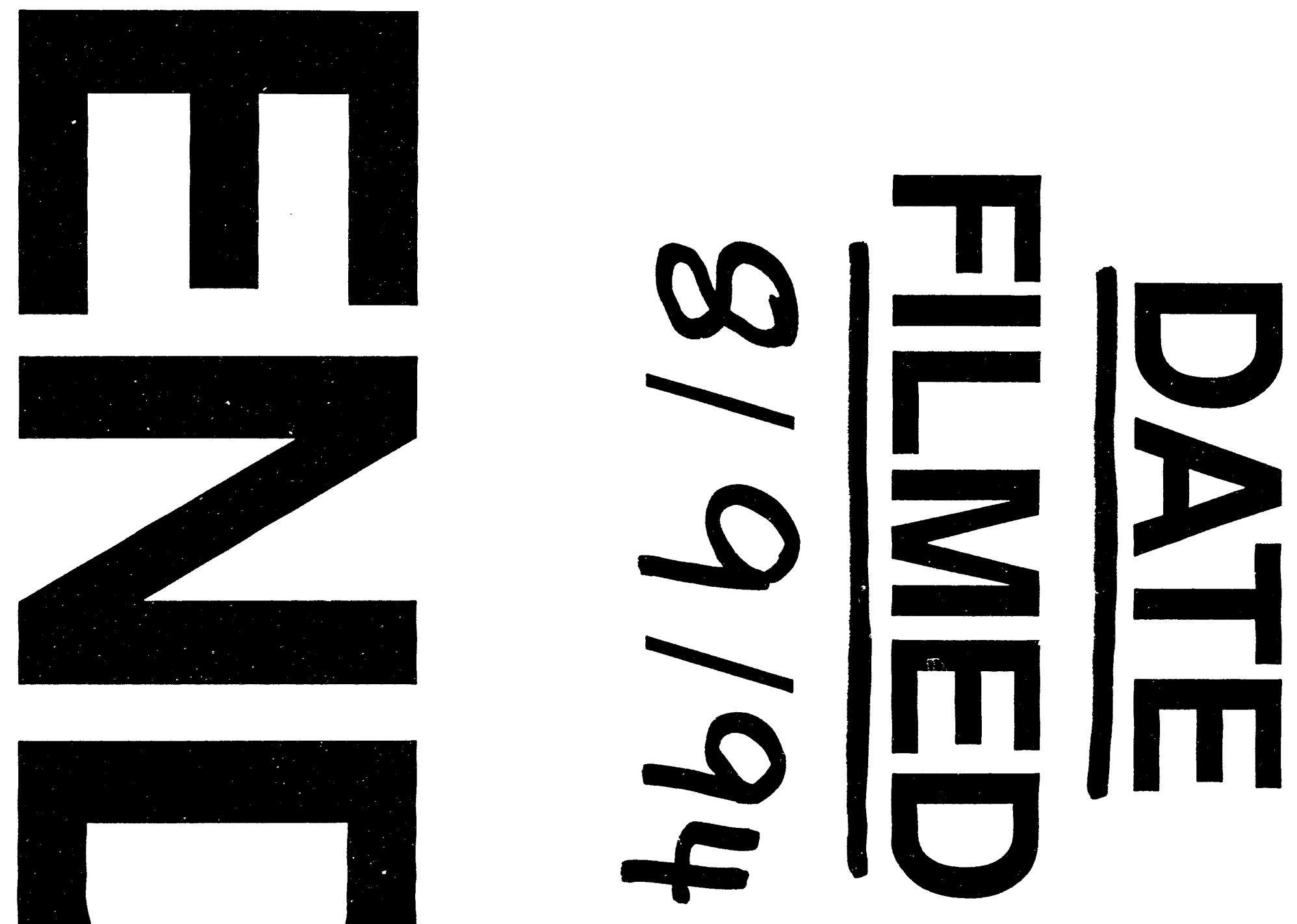
